\title{
LOSS DAN GAIN PADA TERJEMAHAN BUKU HUKUM THE CONCEPT OF LAW KARYA H. L. A HART KE DALAM VERSI BAHASA INDONESIA "KONSEP HUKUM"
}

\author{
Hanifa Pascarina ${ }^{1}$, M. R. Nababan ${ }^{2}$, Riyadi Santosa ${ }^{3}$ \\ ${ }^{1}$ Universitas Sebelas Maret, Surakarta, Indonesia \\ ${ }^{2}$ Professor in Translation at Universitas Sebelas Maret, Surakarta, Indonesia \\ ${ }^{3}$ Professor in SFL at Universitas Sebelas Maret, Surakarta, Indonesia \\ pascarina@rocketmail.com
}

\begin{abstract}
Legal translation is a category of difficult translation of special texts because the language used is registers and the translators are dealing with the different legal systems between BSU (English) and BSA (Indonesia). Translation of English legal texts requires typical techniques to show the right results and to make it understandable as well as to determine the right equivalent. In the process of translation, a translator has the right to use certain techniques to achieve a goal. This study aimed to analyze the application of the techniques Loss and Gain: to identify what is omitted (Loss) and what is added (Gain); discover the causes of Loss and Gain; determine the level of accuracy, acceptability, and readability of translation in the legal book. The Concept of Law. This research employs a descriptive qualitative research with an embedded case study and it is oriented to the translation product. The source of data consists of documents selected with purposive sampling technique and the discussion results with the informant. The documents refer to a legal book The Concept of Law and its translated book. The informants are experts of law study field and understand English and Indonesia. The research data comprises of Loss and Gain in the translation of legal book The Concept of Law and the results of the discussion with the informants. The techniques of collecting data involved document analysis, questionnaires, and focus group discussion. The research data were analyzed using ethnographic analysis by Spradley (1980) which consists of domain, taxonomic, componential, and cultural themes analysis. The findings of the research show that: there are Loss and Gain which occur separately as well as simultaneously in the forms of certain linguistics unit, namely lexical unit, phrase unit, clause unit, and sentence unit; there are four causes of Loss and Gain in translation of legal book The Concept of Law, namely Loss and Gain by the translator himself, knowledge of specific subject/legal jargon, untranslatability, and the use of Latin language; the effects of applying translation techniques Loss and Gain to the translation of legal text towards the quality of its translation show the high level in accuracy, acceptability, and readability level.
\end{abstract}

Keywords: translation technique, loss, gain, translation quality, legal translation, The Concept of Law. 


\section{PENDAHULUAN}

Penerjemahan teks hukum termasuk dalam kategori penerjemahan teks khusus dan sulit dipahami. Untuk dapat mudah dipahami, dalam penerjemahan teks hukum berbahasa Inggris memerlukan teknik yang khas agar hasilnya benar. Terjemahan yang baik harus akurat dan sepadan bila ditinjau dari aspek kebahasaan ataupun hukum sebagai isinya.

Penerjemahan teks hukum sering kali lebih sukar daripada penerjemahan teks bidang lain. Sebagai contoh, seorang penerjemah harus berhadapan dengan masalah perbedaan sistem hukum antara sistem civil law (yang berlaku di Indonesia) dan common law (yang berlaku di Inggris dan negara-negara bekas jajahan Inggris). Pencarian dan pemilihan kata atau istilah yang tepat dan memiliki konsep yang sama dalam teks bahasa sasaran dengan kata atau istilah yang terdapat dalam teks bahasa sumber adalah suatu keharusan yang mutlak untuk menghindari salah tafsir atau salah paham.

Dalam proses penerjemahan, seorang penerjemah berhak menggunakan teknik tertentu untuk mencapai suatu tujuan. Penerjemah mungkin saja menerapkan salah satu teknik yaitu teknik penghilangan dan penambahan informasi (Bassnet-McGuire, 2005). Dengan teknik ini, penerjemah menghilangkan sebagian kata atau makna yang terdapat dalam bahasa sumber ataupun menambahkan kata atau makna yang sebenarnya kata atau makna itu tidak ada atau tidak tersurat dalam bahasa sumber.

Setelah dilakukan beberapa review hasil penelitian sebelumnya, ditemukan beberapa gap penelitian yaitu: (1) terkait topik kajian penerjemahan teks ilmu khusus, masih sedikit yang mengkaji penerjemahan teks hukum; (2) mengenai teori penerjemahan, dalam menganalisis teks hukum yang digunakan penelitian-penelitian sebelumnya sudah terlalu umum, seperti dalam penerapan teori strategi dan teknik penerjemahannya; (3) pembahasan mengenai pengaruh penerapan teknik penerjemahan, khususnya loss dan gain, terhadap kualitas terjemahan suatu produk penerjemahan berupa teks hukum juga belum dibahas pada penelitian sebelumnya. Ketiga hal tersebut mendorong peneliti untuk melakukan penelitian kajian penerjemahan teks hukum dengan menganalisis teknik penerjemahan loss dan gain yang diterapkan dalam menerjemahkan produk penerjemahan yaitu buku bidang hukum, The Concept Of Law oleh H. L. A Hart menjadi Konsep Hukum oleh M. Khozim. 


\section{TEORI DAN METODOLOGI}

\section{Penerjemahan}

Penerjemahan bukan semata-mata mengalihkan teks dari BSu ke dalam BSa. Akan tetapi, inti dari terjemahan itu adalah tersampaikannya makna atau informasi dari BSu ke dalam BSa. Penerjemahan merupakan upaya untuk mengganti teks bahasa sumber ke dalam teks yang sepadan dengan bahasa sasaran. Tujuan pokok menerjemahkan adalah untuk mengalihkan pesan yang tertulis dalam BSu ke dalam BSa dengan mengutamakan kesepadanan makna (Newmark, 1981: 7). Dengan demikian, inti dari penerjemahan adalah suatu kegiatan yang menyangkut keterkaitan antara dua bahasa atau lebih yang kemudian terdapat transfer makna bahasa sumber ke bahasa sasaran dengan letepatan pesan sehingga bermuara pada produk penerjemahan yang baik.

\section{Teknik penerjemahan}

Molina dan Albir (2002: 509) mendefinisikan teknik penerjemahan sebagai "procedure to analyze and classify how translation equivalence works." Hal tersebut mengacu pada langkah-langkah yang dilakukan penerjemah untuk menerjemahkan.

Setiap pakar memiliki istilah tersendiri dalam menentukan suatu teknik penerjemahan. Teknik yang dimaksud sama namun memiliki istilah yang berbeda. Seperti pada penyebutan teknik penerjemahan penghilangan dan penambahan. Dalam hal keberagaman tentunya hal ini bersifat positif, namun di sisi lain terkait penelitian akan menimbulkan kesulitan dalam menentukan istilah suatu teknik tertentu. Oleh karena itu, dalam penelitian ini menggunakan teknik penerjemahan penghilangan dan pengurangan yang dikemukakan oleh Bassnet-McGuire (2005) dengan istilah loss dan gain.

\section{Konsep Loss Dan Gain}

Dalam proses penerjemahan terdapat hal yang disebut dengan modifikasi makna dalam terjemahan. Hal ini dikarenakan proses penerjemahan melibatkan dua bahasa yang mempunyai sistem dan karakteristik penyampaian pesan yang berbeda-beda. Modifikasi makna ini dimaksudkan untuk memperjelas pesan berdasarkan konteks tuturan dalam terjemahan, sahingga makna itu mudah dimengerti oleh pembaca. Dalam proses modifikasi tersebut penerjemah mungkin saja mengurangi makna yang 
sebenarnya makna itu ada di dalam BSu atau bahkan penerjemah menambahkan makna tertentu dalam terjemahan.

Loss dalam penerjemahan berarti adanya istilah atau konsep makna yang terdapat dalam BSu, tetapi tidak tersampaikan dalam BSa (Bassnet-McGuire, 2005: 38). Intinya, ada informasi, makna atau kata yang hilang dalam terjemahan. Dengan kata lain, loss dan gain atau istilahnya dalam bahasa Indonesia penambahan dan pengurangan adalah peristiwa hilangnya kata atau makna asal dalam teks terjemahan dan terjadinya penambahan kata atau makna dalam teks terjemahan.

Terjadinya loss dan gain dalam penerjemahan, khususnya dalam penerjemahan hukum, bisa disebabkan oleh beberapa hal. Menurut Nozizwe dan Ncube (2014) terjadinya loss dan gain disebabkan oleh penggunaan Bahasa Latin, pengetahuan akan subyek tertentu/legal jargon, perbedaan jarak linguistik (linguistic distance), ketidakterjemahan "untranslatability", linguistic disparities, dan distance between culture. Scandura (2004: 126) menambahkan bahwa penghilangan dapat disebabkan karena alasan penghilangan oleh diri sendiri atau penerjemah itu sendiri (selfcensorship), agama, politik, dan political correctness.

\section{Penerjemahan Teks Hukum}

Penerjemahan teks hukum merupakan hal yang kompleks karena tidak hanya menyangkut persoalan trans-bahasa dan peristilahan, melainkan juga aspek-aspek nonkebahasaan yang berkaitan dengan teks sumber yang diterjemahkan. Seorang penerjemah dituntut agar mempunyai perangkat yang dapat membantunya dalam penerjemahan teks sumber, sehingga ia dapat menerjemahkan teks tersebut secara tepat dan benar, khususnya dibidang hukum.

Sifat bahasa hukum dalam sebuah teks hukum terletak pada istilah-istilah, komposisi serta gaya bahasanya yang khusus dan kandungan artinya yang khusus (Maronie, 2013). Di dalam media tertulis, bahasa yang dipergunakan di dalam teks hukum sangat berbeda dengan bahasa yang dipergunakan di dalam jenis teks lain. Trosborg dalam Djatmika (2015: 100) mengungkapkan bahwa jenis teks ini (teks hukum) sangat khas dengan kompleksitas kalimat yang dipergunakan. Dengan demikian, teks hukum tersebut seringkali sangat sulit dipahami.

Dalam prakteknya, terdapat istilah-istilah dan bahasa hukum, yang sulit dipahami atau dimengerti, tidak saja oleh mereka yang bukan berlatar belakang 
pendidikan dan pekerjaan di luar ilmu hukum, tetapi bahkan juga oleh kalangan praktisi dan akademisi hukum yang sehari-hari profesinya bergelut di bidang itu sendiri.

Perlu dipikirkan untuk menyusun bahasa hukum yang lebih singkat, jelas, mudah di pahami dan dimengerti serta sesuai dengan kaidah-kaidah bahasa Indonesia. Soleh (dalam Naning, 2008: 29-30) mengatakan bahwa disamping faktor rasa estetika, bahasa hukum harus komunikatif, singkat, jelas, tidak bertele-tele serta tidak melanggar kaidah-kaidah bahasa Indonesia serta memiliki rasa estetika.

\section{Penilaian Kualitas Terjemahan}

Terjemahan disebut baik apabila berorientasi pada pembaca atau pendengar. Oleh karena itu, penguasaan BSa sangat penting. Penerjemah yang berspesialisasi seperti hukum, harus menguasai substansi yang diterjemahkannya.

Penilaian terhadap kualitas terjemahan akan memberikan manfaat bagi pembaca teks sasaran, penerjemah professional, peneliti di bidang penerjemahan. Bagi pembaca teks bahasa sasaran, hasil penilaian kualitas terjemahan dapat digunakan sebagai patokan apakah penerjemah yang menghasilkan terjemahan tersebut dipercaya atau tidak.

Nababan (2012: 44) mengemukakan bahwa terjemahan yang berkualitas harus memenuhi tiga aspek, yaitu aspek keakuratan, keberterimaan dan keterbacaan. Ketiga aspek tersebut merupakan parameter kualitas terjemahan yang saling berkaitan satu sama lain. Keakuratan merupakan aspek yang digunakan dalam pengevaluasian terjemahan utnuk merujuk pada apakah teks bahasa sumber dan teks bahasa sasarna sudah sepadan atau belum. Kemudian, keberterimaan merujuk pada apakah suatu terjemahan sudah diungkapkan sesuai dengan kaidah-kaidah, norma dan budaya yang berlaku dalam bahasa sasaran ataukah belum, baik pada tataran mikro maupun pada tataran makro. Sedangkan, Keterbacaan merupakan aspek yang hanya dikaitkan dengan kegiatan membaca karena setiap kegiatan menerjemahkan tidak bisa lepas dari kegiatan membaca. Aspek keterbacaan tidak hanya menyangkut keterbacaan teks bahasa sumber tetapi juga keterbacaan teks bahasa sasaran.

\section{Metode Penelitian}

Penelitian ini merupakan penelitian di bidang penerjemahan, dengan berfokus pada produk terjemahan (product-oriented). Produk terjemahan yang akan dikaji disini adalah penggunaan teknik penerjemahan loss dan gain pada buku The Concept of Law 
dan versi terjemahannya. Penelitian ini merupakan penelitian di bidang penerjemahan yang tergolong deskriptif kualitatif.

Data yang akan dikaji dalam penelitian ini terdiri dari dua jenis, yaitu data primer yang diperoleh dengan cara mengumpulkan bentuk atau wujud loss dan gain dalam buku The Concept of Law oleh H. L. A. Hart, versi bahasa Inggris maupun bahasa Indonesia dan data primer berikutnya adalah faktor penyebab loss dan gain tersebut, serta hasil kuesioner berupa penilaian kualitas terjemahan mengenai tingkat keakuratan, keberterimaan, dan keterbacaan dari informan atau rater. Di sisi lain, data sekunder dalam penelitian ini berupa informasi dan ulasan-ulasan mengenai beberapa penelitian sebelumnya yang mengkaji penerjemahan hukum sebagai referensi oleh peneliti.

Penelitian ini menggunakan teknik purposive sampling. Sampling dilakukan agar sampel yang diperoleh dapat mengantarkan peneliti mencapai tujuan peneliti. Jadi, dalam penelitian kualitatif, cuplikan yang diambil lebih bersifat selektif. Pilihan sampel diarahkan pada sumber data yang dipandang memiliki data penting yang berkaitan dengan permasalahan yang sedang diteliti.

Dalam penelitian ini, pengumpulan data dilakukan dengan tiga cara yaitu mengkaji dokumen (content analysis), kuesioner, dan Focus Group Discussion (FGD).

Tahapan analisis data yang digunakan dalam penelitian ini diambil dari empat tahap analisis data menurut Spradley (1980) yang meliputi analisis domain, analisis taksonomi, analisis komponensial, dan analisis tema budaya.

\section{HASIL DAN PEMBAHASAN}

Dalam penelitian bersumber pada dokumen atau buku teks Hukum The Concept of Law yang diterjemahkan menjadi Konsep Hukum ini ditemukan peristiwa Loss dan Gain yang tidak hanya terjadi sendiri-sendiri, namun juga yang terjadi bersamaan. Pengkajian buku tersebut mendapatkan data peristiwa Loss dan Gain sebanyak 247.

\section{Bentuk Loss dan Gain}

Penerapan teknik penerjemahan Gain lebih besar (131) diterapkan oleh penerjemah dalam menerjemahkan kalimat dalam buku Hukum The Concept of Law 
daripada penerapan teknik penerjemahan Loss (116). Penerapan teknik Loss dan Gain dalam penelitian ini sebagian besar diterapkan dalam bentuk atau tataran kata (52 Loss, 95 Gain) dan yang kedua yaitu dalam bentuk frasa (47 Loss, 34 Gain). Hal ini dikarenakan pada tataran kata maupun frasa sebagian besar berhubungan dengan bidang Hukum. Penerjemah menyadari bahwa dirinya tidak memahami ilmu Hukum sehingga menerapkan penambahan penjelasan dalam kurung tutup akan kata tersebut. Penjelasan tersebut berupa kata atau frasa asli berbahasa Inggris dari kata atau frasa tersebut. Disamping itu, pada tataran kata lebih banyak kata yang berupa hal kecil atau tidak dianggap penting bagi penerjemah apabila menghilangkannya dalam $\mathrm{BSa}$, seperti sebuah kata ganti/pronoun, kata hubung/konjungsi, kata sifat, auxiliary, determiner, adverb, preposition. Pada bagian frasa yang sebagian besar bermuatan ilmu Hukum, penerjemah kesulitan untuk menerjemahkannya sesuai dengan sistem yang berlaku pada BSa (Indonesia) sehingga tetap meminjam frasa aslinya dalam bahasa Inggris atau Latin tanpa memberi penjelasan tambahan karena tidak menemukan atau menentukan padanannya yang sesuai.

Sesuai dengan teori Loss dan Gain yang diutarakan oleh Bassnet-McGuire (2005), penghilangan atau Loss dalam penelitian ini yaitu tidak diterjemahkannya/ penghilangan makna tau kata atau tidak mengalihkan bahasa pada bagian BSu ke dalam BSa. Sedangkan, penambahan atau Gain dalam penelitian ini yaitu terdapat penambahan informasi, makna atau kata yang sebelumnya tidak ada pada BSu menjadi ada pada BSa. Penemuan wujud Loss dan Gain dalam terjemahan Buku Hukum The Concept of Law ini mendukung atau sesuai dengan teori mengenai teknik penerjemahan yang telah dikembangkan oleh Molina dan Albir (2002) bahwa suatu teknik penerjemahan merupakan cara untuk mengalihkan pesan dari BSu ke BSa yang diterapkan pada tataran micro unit (kata, frasa, klausa, maupun kalimat)

Penerjemah melakukan teknik penghilangan ini agar terjemahan yang dihasilkan dapat lebih jelas sehingga dapat dipahami dengan baik oleh pembaca sasaran. Penghilangan ini juga bertujuan untuk membuat kalimat terjemahan lebih nyaman atau sesuai dibaca. Namun selain itu ditemukan juga Loss yang menyebabkan kalimat terjemahan justru terlihat rancu karena ada bagian yang hilang, sehingga pesan yang disampaikan kurang jelas. Hal ini juga menyebabkan pembaca harus membaca terjemahan tersebut berulang kali untuk dapat mengerti pesan yang disampaikan. 
Seperti halnya pada penerapan Loss, penerapan teknik Gain atau penambahan informasi dilakukan penerjemah agar terjemahan yang dihasilkan dapat lebih jelas, pesan tersampaikan dengan tepat, dan dapat dipahami pembaca sasaran. Selain itu, penambahan dalam penelitian ini sebagian besar dilakukan penerjemah dalam menambahkan kata asli dari suatu istilah. Apabila istilah tersebut sudah dialihkan bahasanya dalam BSa, penerjemah menambahkan kata asli (bahasa Inggris) istilah tersebut di dalam kurung. Namun sebaliknya apabila istilah tersebut tidak dialihkan ke dalam BSa (Indonesia), penerjemah menyertakan istilah aslinya (Inggris) atau menambahkannya di dalam kurung. Hal ini dikarenakan teks terjemahan ini berupa teks bidang khusus yaitu Hukum sehingga banyak kata atau istilah yang harus disesuaikan dengan sistem Hukum BSa atau Indonesia yang berbeda dengan sistem pada BSu (Inggris). Dengan melihat peristiwa penambahan ini nampaknya penerjemah tidak ahli dalam ilmu Hukum karena penerjemah nampak ragu dalam menejemahkan kata atau istilah yang merupakan istilah bidang Hukum sehingga menyertakan kata aslinya dalam bahasa Inggris atau yang tercantum pada BSu, selain itu juga masih terdapat kata atau istilah yang tidak disesuaikan dengan sistem Hukum BSa (Indonesia). Menurut Nida (1964: 227), penambahan atau Gain dimaksudkan untuk menambahkan informasi dalam terjemahan dengan tujuan tertentu. Hal ini dibuktikan dalam hasil penemuan Gain pada penelitian ini yaitu Gain pada penelitian ini dilakukan dengan menambahkan informasi dalam terjemahan dengan tujuan tertentu, yaitu adanya bagian dalam bahasa sasaran yang merujuk pada bidang khusus yaitu Hukum yang apabila tidak diberikan penjelasan tambahan akan disalahartikan atau tidak dipahami oleh pembaca.

Berkaitan dengan Loss dan Gain yang terjadi bersamaan, Loss dan Gain dalam penelitian ini cenderung dapat membuat kalimat terjemahan lebih wajar dan lebih jelas sehingga dapat dipahami oleh pembaca sasaran. Hal ini sesuai dengan teori Loss dan Gain yang dikembangkan oleh pakar penerjemah bahwa teknik penerjemahan penghilangan dan penambahan informasi ini dapat menjadikan karya terjemahan lebih wajar sehingga dapat dinikmati oleh pembaca sasaran.

Penemuan pada penelitian terhadap terjemahan buku Hukum The Concept of Law ini mendukung pula pada hasil penemuan dari penelitian-penelitian sebelumnya mengenai penerjemahan teks bidang khusus yaitu Hukum bahwa dengan banyaknya kata-kata khusus yang muncul dan sulit dipahami, begitu juga dengan adanya perbedaan 
sistem Hukum pada BSu (Inggris) dan BSa (Indonesia), untuk menghindari ketidakjelasan pada terjemahan yang mana ketidakjelasan tersebut dapat muncul sebagai keambiguan pada sebuah kalimat terjemahan, penerjemah harus memiliki formula atau cara yang inovatif untuk mengatasinya (Witczak, 2009 dan Cozma, 2010). Seperti pada contoh yang diutarakan oleh Gocić (2012) bahwa konjungsi dan (and) dan atau (or) dapat menjadi penghubung yang dapat menyebabkan ketidakjelasan atau bisa juga ambiguitas. Dalam menerjemahkan kalimat yang terdapat konjungsi di dalamnya seharusnya hati-hati dipilih oleh penerjemah dalam upaya untuk mencegah ketidakjelasan maupun keambiguan dalam teks-teks hukum. Penerjemah harus dapat memutuskan bahwa apakah sebuah kata itu layak dipertahankan atau tidak agar tidak menimbulkan ketidakjelasan atau ketidakwajaran dalam terjemahan. Sesuai pula dengan hasil penemuan pada penelitian ini bahwa dengan adanya perbedaan sistem Hukum pada BSu dan BSa, serta kata-kata yang bermuatan ilmu Hukum membuat penerjemah kesulitan menemukan padanan yang sesuai, sehingga penerjemah menerapkan teknik Loss dan Gain untuk mengatasinya. Dengan Gain penerjemah dapat menambahkan penjelasan tambahan pada kata-kata yang bermuatan Hukum, sedangkan dengan Loss penerjemah dapat menentukan kata-kata mana saja yang perlu dipertahankan atau tidak agar tidak menimbulkan kerancuan atau ketidakjelasan dalam terjemahan. Hal ini dilakukan penerjemah untuk menghindari ketidakjelasan terjemahan agar terjemahan dapat lebih wajar.

\section{Penyebab Loss dan Gain}

Berdasarkan pada teori penghilangan dan penambahan oleh Nozizwe\&Ncube (2014) dan Scandura (2004), terjadinya penghilangan (Loss) dan penambahan (Gain) pada terjemahan buku Hukum The Concept of Law disebabkan oleh beberapa faktor yaitu (1) penghilangan atau penambahan yang disengaja/oleh penerjemah sendiri; (2) adanya pengetahuan akan subjek tertentu/legal jargon; (3) untranslatability; dan (4) penggunaan bahasa Latin.

Terjadinya Loss dan Gain pada terjemahan buku Hukum The Concept of Law ini cenderung disebabkan oleh penerjemah itu sendiri yang sengaja menghilangkan dan menambahkan kata atau makna pada saat menerjemahkan untuk membuat terjemahan tersebut tidak terkesan panjang atau berbelit-belit, membuat terjemahan lebih wajar atau 
enak dibaca dan dipahami pesannya oleh pembaca sasaran. Selanjutnya, Loss dan Gain pada penelitian ini juga cenderung disebabkan oleh pengetahuan akan subjek tertentu atau legal jargon. Hal ini karena objek penelitian ini merupakan teks bidang khusus yaitu Hukum dimana teks ini sensitif dengan ilmu tertentu yaitu Hukum itu sendiri atau memuat kata dan istilah-istilah dalam bidang Hukum. Seperti yang telah dipahami bahwa istilah-istilah dalam ilmu Hukum memiliki padanan yang berbeda dengan istilahistilah secara umum. Perbedaan sistem hukum pada BSu (Inggris) dan sistem Hukum BSa (Indonesia) juga dapat mempengaruhi padanan tersebut. Apabila penerjemah menjumpai sebuah istilah khusus ilmu Hukum pada BSu, penerjemah harus dapat mengalihkannya dalam BSa dengan disesuaikan sistem Hukum yang berlaku pada BSa (Indonesia), misalnya terdapat istilah primitive law dan dialihkan menjadi hukum adat bukan bukan primitif pada BSa karena menyesuaikan apa yang sudah dikenal atau lazim dalam Hukum di Indonesia.

Penyebab terjadinya Loss dan Gain yang lain pada penelitian ini adalah untranslatability dan penggunaan bahasa Latin. Untranslatability atau ketidakterjemahan merupakan penyebab terjadinya Loss dan Gain dimana terdapat bagian BSu yang tidak dapat dialihkan ke dalam BSa ataupun diganti dengan makna lain pada BSa dan tidak mengalami tambahan apapaun atau penjelasan dalam tanda kurung. Bagian BSu tersebut tetap berdiri sendiri dengan kata atau istilah aslinya BSu (dalam Bahasa Inggris) dan tidak ada padanannya dalam BSa yang sesuai dengan sistem Hukum BSa (Indonesia), karena kata atau istilah tersebut hanya berlaku atau eksis di sistem Hukum BSu (Inggris) dan hanya dikenal/dipahami di dalam sistem tersebut. Sehingga penerjemah tidak bisa menerjemahkannya.

Faktor penyebab lain terjadinya Loss dan Gain yaitu karena adanya bahasa Latin. Dalam penelitian terhadap terjemahan buku Hukum The Concept of Law ini ditemukan adanya istilah-istilah Latin. Hal ini sesuai dengan teori Nozizwe\&Ncube (2014) mengenai penerjemahan Hukum bahwa dalam teks Hukum akan ada banyak kata atau istilah yang sudah terspesialisaikan dalam bahasa Latin maupun Inggris. Kata atau istilah dalam bahasa Latin ini tidak diterjemahkan oleh penerjemah karena ketidaktahuan penerjemah mengenai bahasa Latin tersebut. Bahasa Latin tersebut dapat diterjemahkan oleh penerjemah dengan bantuan orang yang mengerti bahasa Latin dan dapat pula melalui bantuan kamus bahasa Latin atau mencari tahu padanannya yang 
tepat dengan browsing internet. Namun, penggunaan bahasa Latin sebagai faktor penyebab terjadinya Loss dan Gain pada penelitian ini tidak mengalami pengalihan bahasa pada BSa.

Dari ke empat faktor tersebut, faktor yang mempengaruhi terjadinya Loss yaitu sebagian besar dipengaruhi oleh faktor penghilangan oleh penerjemah itu sendiri, selanjutnya oleh faktor untranslatability, faktor pengetahuan akan subjek tertentu/legal jargon, dan faktor penggunaan bahasa Latin. Sedangkan faktor yang mempengaruhi terjadinya Gain yaitu sebagian besar dipengaruhi oleh faktor penambahan oleh penerjemah itu sendiri, faktor pengetahuan akan subjek tertentu/legal jargon, dan faktor untranslatability. Dari penemuan tersebut terlihat bahwa faktor yang menyebabkan Loss yaitu karena faktor penghilangan oleh penerjemah itu sendiri dan unstranslatability. Sementara itu, faktor yang paling dominan mempengaruhi terjadinya Gain yaitu faktor penambahan oleh penerjemah itu sendiri dan faktor pengetahuan akan subjek tertentu.

Berkaitan dengan penerapan teknik penerjemahan Loss dan Gain karena faktor penerjemah itu sendiri, dapat disampaikan bahwa dalam penerapan suatu teknik penerjemahan, seorang penerjemah harus menyadari bahwa yang dilakukan itu adalah suatu optional (pilihan) atau obligatory (kewajiban). Berkaitan dengan hal tersebut maka dapat disimpulkan bahwa dalam menerjemahkan buku Hukum The Concept of Law penerjemah wajib melakukan teknik ini mengingat terdapat perbedaan struktur atau sistem bahasa Inggris dan bahasa Indonesia dan perbedaan sistem Hukum antara sistem Hukum yang dianut oleh BSu (Inggris) dan BSa (Indonesia). Apabila teknik ini tidak diterapkan oleh penerjemah, maka hasil terjemahan tidak tepat atau tidak berterima dalam bahasa Indonesia sebagai bahasa sasaran, namun dalam penelitian ini juga terdapat kata-kata yang tidak wajib diterjemahkan, yang artinya bahwa kata-kata tersebut bisa dihilangkan atau ditambahkan informasi maupun tidak perlu dihilangkan atau ditambahkan karena tidak berpengaruh buruk terhadap pesan yang disampaikan BSu dan tidak berkaitan dengan istilah Hukum yang memerlukan kesesuaian terhadap dua sistem Hukum yang berbeda.

\section{Pengaruh Loss dan Gain terhadap Kualitas Terjemahan}

Loss atau penghilangan informasi dalam penelitian terhadap buku Hukum The Concept of Law ini ternyata mempengaruhi keakuratan terjemahan. Sebagian besar terjemahan buku tersebut termasuk dalam kategori akurat pada skor tertinggi yaitu 3 
dengan besar $75,86 \%$, sedangkan terjemahan yang termasuk kategori kurang akurat sebanyak 24,14\%. Penghilangan atau Loss dalam penelitian ini terdapat pada satuan lingual tertentu (kata, frasa, klausa, atau kalimat) yang memiliki makna atau mengandung pesan tetapi tidak disampaikan dalam BSa. Secara umum penerjemah dalam menerjemahkan buku Hukum The Concept of Law tersebut nampak sengaja melakukan penghilangan dalam satuan lingual tertentu karena menganggap bahwa penghilangan ini tidak bermasalah seperti mengubah isi/pesan yang terkandung pada BSu dan makna dari bagian yang dihilangkan tersebut sudah tercakup keseluruhan pada terjemahan. Sehingga, meski mengalami penghilangan pada satuan lingual tertentu namun sebagian besar kalimatnya dialihkan dengan tepat atau akurat, tingkat keakuratan menjadi tinggi. Namun apabila penghilangan tersebut mengubah keutuhan pesan, maka keakuratan menurun yaitu pada skor 2 menjadi kurang akurat.

Loss juga mempengaruhi keberterimaan. Terjemahan buku Hukum The Concept of Law menghasilkan terjemahan berterima dan kurang berterima. Hal ini mengindikasikan bahwa penerapan Loss atau penghilangan dalam penelitian ini berpengaruh positif dan berpengaruh negatif, artinya seimbang, ada yang baik dan ada yang buruk. Dengan penghilangan, terjemahan dapat menjadi lebih wajar dan dapat sesuai dengan kaidah bahasa Indonesia, sehingga berterima. Dengan penghilangan juga, terjemahan dapat menghasilkan terjemahan yang kurang sesuai dan masih terdapat kesalahan, sehingga terjemahan menjadi kurang berterima. Dengan demikian hasil terjemahan ini sebagian dapat dipahami dan sebagian tidak dapat dipahami oleh pembaca sasaran. Sedangkan hasil penelitian tingkat keterbacaan adalah sebagian besar terjemahan buku Hukum The Concept of Law mudah dipahami oleh pembaca sasaran yaitu pembaca yang memang berkecimpung di dunia Hukum sesuai dengan bidang buku tersebut.

Gain atau penambahan informasi pada penelitian ini dilakukan dengan menambahkan satuan lingual tertentu yaitu bagian yang tidak terdapat pada BSu tetapi ada atau muncul dalam BSa. Sebagian besar Gain pada penelitian ini berpengaruh positif terhadap keakuratan. Hal ini ditunjukkan dengan hasil yang didapat dari penelitian ini bahwa $82,44 \%$ terjemahan buku Hukum The Concept of Law tersebut akurat. Hal ini dikarenakan sebagian besar penerapan Gain ini berguna untuk membuat terjemahan lebih jelas karena adanya perbedaan budaya atau dalam konteks ini 
perbedaan sistem yaitu sistem Hukum BSu (Inggris) dan BSa (Indonesia) sehingga memerlukan penambahan penjelasan.

Selain itu, Gain pada terjemahan buku Hukum The Concept of Law ini juga berpengaruh positif terhadap keberterimaan. Hal ini dibuktikan dengan hasil bahwa sebagian besar terjemahan $72,52 \%$ berterima, karena dengan penambahan informasi penerjemah dapat menangani atau menyusun bahasa secara inovatif untuk menghasilkan terjemahan dengan kata-kata yang lazim dan akrab oleh pembaca sasaran.

Disamping keakuratan Gain tinggi pada skor 3 dan keberterimaannya, pada penelitian ini juga ditemukan bahwa keterbacaan terjemahan juga tinggi yaitu pada skor 3. Penambahan informasi dapat membantu pembaca sasaran dalam memahami suatu kalimat sehingga kalimat dapat mudah terbaca dan dipahami maksudnya oleh pembaca sasaran.

Selain Loss dan Gain yang terjadi terpisah, peristiwa Loss dan Gain juga terjadi bersamaan. Dalam penelitian ini menghasilkan tingkat keakuratan pada skor 3 yaitu paling tinggi, sedangkan untuk keberterimaan sebagian besar cenderung berterima. Aspek berikutnya yaitu keterbacaan, penelitian ini juga menemukan bahwa peristiwa Loss dan Gain bersamaan ini menciptakan keterbacaan yang tinggi.

Penerapan teknik Gain oleh penerjemah dalam buku Hukum The Concept of Law menghasilkan terjemahan yang akurat, begitu juga dengan Loss. Sebagian penambahan merupakan penjelas, sedangkan pengurangan berupa pengurangan akan bagian yang tidak terlalu penting dan berpengaruh buruk terhadap isi kalimat terjemahan. Teknik penerjemahan Loss atau penghilangan informasi dan Gain atau penambahan informasi berdampak positif dalam terjemahan buku Hukum The Concept of Law. Ini berarti bahwa dengan Loss dan Gain yang terjadi terpisah maupun bersamaan menghasilkan terjemahan yang akurat, berterima, dan terbaca tinggi. Hal ini dikarenakan penerapan Loss dan Gain ini merupakan usaha penerjemah dalam menghasilkan terjemahan yang wajar dengan menambahkan dan menghilangkan bagian tertentu sehingga lebih terbaca dan dipahami oleh pembaca sasaran. 


\section{SIMPULAN}

Simpulan yang dapat diambil dari penelitian ini adalah:

1. Loss dan Gain yang ditemukan dalam buku Hukum tersebut berjumlah 247 (116 Loss dan 131 Gain) yang terdiri dari 72 terjemahan yang telah mengalami penghilangann informasi atau Loss atau yang terjadi terpisah, 84 terjemahan yang telah mengalami penambahan informasi atau Gain yang terjadi terpisah, dan 91 terjemahan dengan peristiwa Loss dan Gain yang terjadi bersamaan.

2. Wujud Loss dan Gain yang banyak berkontribusi pada penelitian terhadap buku Hukum The Concept of Law dan terjemahannya adalah dalam bentuk kata, dalam total jumlah 147 (52 Loss dan 95 Gain). Dengan demikian, terjemahan buku Hukum The Concept of Law mengandung lebih banyak Gain daripada Loss dalam wujud kata.

3. Faktor penyebab terjadinya Loss dan Gain dalam terjemahan buku Hukum The Concept of Law ini banyak dikarenakan faktor penghilangan dan penambahan yang disengaja oleh penerjemah sendiri (obligatory atau optional) untuk membuat terjemahan terkesan singkat atau tidak berbelit-belit, lebih jelas, lebih mudah dipahami oleh pembaca sasaran. Faktor yang kedua adalah faktor pengetahuan akan subjek tertentu, karena kata atau makna yang dihilangkan maupun ditambahkan tersebut merujuk pada istilah khusus, berhubungan dengan subjek tertentu sesuai dengan teks yang diteliti yaitu bidang Hukum atau yang disebut dengan legal jargon.

4. Penerapan teknik penerjemahan Loss dan Gain pada buku The Concept of Law dan terjemahannya memiliki dampak positif bagi terjemahan. Sebagian penambahan merupakan penjelas sehingga dapat memperjelas isi kalimat terjemahan, sedangkan pengurangan berupa pengurangan akan bagian yang tidak terlalu penting dan berpengaruh buruk terhadap isi kalimat terjemahan. Selain itu, penerapan Loss dan Gain ini menghasilkan terjemahan yang wajar dengan menambahkan dan menghilangkan bagian tertentu sehingga lebih terbaca dan dipahami oleh pembaca sasaran.

5. Terjemahan buku Hukum The Concept of Law ini akurat, berterima, dan terbaca. 


\section{SARAN}

\section{Bagi Penerjemah:}

a. Penerjemahan buku Hukum harus memperhatikan sifatnya yang sensitif, keterlibatan lebih dari dua bahasa, dan perbedaan sistem Hukum pada BSu (Inggris) dan BSa (Indonesia).

b. Penerapan teknik penerjemahan Loss harus hati-hati agar tidak mendistorsi makna yang membuat terjemahan tidak jelas dan tidak dapat dipahami. Begitu juga dengan penerapan Gain juga harus dilakukan secara cermat dan hati-hati.

c. Penerjemah perlu meningkatkan kemampuannya dalam bahasa Inggris dan bahasa Indonesia dan belajar lebih banyak mengenai konsep penerjemahan sebagai pedoman penting dalam melakukan kegiatan penerjemahan.

d. Penerjemah disarankan agar gigih dalam mencari padanan atau makna dari istilahistilah khusus dalam bidang Hukum.

\section{Bagi Penyunting atau Editor:}

Disarankan menyunting teks yang akan diterbitkan disesuaikan dengan BSu/teks asli, setidaknya penyunting/editor harus mengerti $\mathrm{BSu}$, pernah mencocokkan buku terjemahan dengan buku sumber.

\section{Bagi Pembaca:}

Agar pembaca mampu memilih buku-buku terjemahan buku ilmiah yang baik dan tepat. Tidak hanya melihat siapa yang menerjemahkan tetapi juga dilihat hasil penerjemahannya.

\section{DAFTAR PUSTAKA}

Bassnet-McGuire, S. (2005). translation studies. London: Routledge.

Bell, R. T. (1991). Translation and translating: Theory and practice. London and New York: Longman.

Cozma, M. (2010). Semantic peculiarities in the legal discourse: A translation-oriented approach. Professional communication and translation studies, 3 (1-2) / 2010 . University of the West, Timişoara. 
Djatmika. (2014). Pernik kajian wacana. Yogyakarta: Graha Ilmu.

Gocić, M. S. (2012). Cohesive devices in legal discourse. Facta universitatis series: Linguistics and literature vol. 10, No 2, 2012, pp. 89 - 98. College of Applied Vocational Studies, Vranje, Serbia.

Hart, H. L. A. (1997). The concept of law. New York: Clarendon Press.

Khozim, M. (2011). Konsep hukum (The concept of law, H. LA. Hart). Bandung: Nusa Media.

Maronie, S. (2013). Pengertian dan kegunaan bahasa hukum. Diambil dari www.sheriefmaronie.com.

Molina, L., dan Albir, A. H. (2002). Translation techniques revisited: A dynamic and functionalist approach. Meta: Translator's journal, 47 (4), 498-512.

Nababan, M. R., Nuraeni, A., dan Sumardiono. (2012). Pengembangan Model Penilaian Kualitas Terjemahan. Jurnal Kajian Linguistik dan Sastra. Vol. 24. No. 1.

Naning, R. (2008). Penerjemah teks hukum dalam praktek. Artikel varia advokat Volume 07, Oktober 2008. Diambil dari variaadvokat.awardspace.info/vol7.

Newmark, P. (1981). Approaches to translation. Oxford: Pergamon Press.

Nida, E. A. (1964). Toward a science of translating. Leiden: E. J. Brill.

Nozizwe, D., dan Ncube, B. (2014). A Case of court translations. African journal of scientific research (AJSR) vol. 12, No. 1 (2014) ISSN 2220-9433. Journals Bank.

Scandura, G. L. (2004). Sex, lies, and tv: cencorship and subtitling. Meta: Journal des traducteurs/Meta: Translators' journal, vol. 49, no. 1, 2004, p. 125-134.

Spradley, J. (2007). Metode etnografi. Yogyakarta: Pt. Tiara Wacana

Witczak-Plisiecka, I. (2009). A linguistic-pragmatic note on indeterminacy in legal language. Linguistica copernicana nr 1 (1) / 2009. Department of Łódź. 